\title{
Physicochemical Properties and Yield of Tomato Varieties under Plastic House Condition
}

\author{
Tika R. Chapagain, Dev N. Tiwari, Ram C. Adhikari and Man B. Shrestha \\ Nepal Agricultural Research Council, Kathmandu, Nepal \\ e-mail: chapagaintika@gmail.com
}

\begin{abstract}
Seven tomato varieties, Ahmita, BL-410, Ceres, Dalila, Makish, Srijana and Winsari were evaluated for physicochemical properties and fruit yield under plastic house condition during rainy seasons of two consecutive years 2012 and 2013 at the Regional Agriculture Research Station, Lumle, Kaski . The experiment was laid out in a complete randomized block design with four replications. The physicochemical analyses revealed that BL-410 had the highest total soluble solid $\left(5.22^{\circ} \mathrm{Bx}\right)$ while Srijana had the highest tritrable acidity $(0.903 \%)$ and vitamic $\mathrm{C}$ content (32.32 mg/100 g). It showed that Srijana was the most useful variety from nutritional perspective. BL-410 took least time to flowering (22.00 days), fruiting (28.00 days) and first harvesting (72.00 days) after transplanting. Ahmita produced maximum number of fruits per cluster (8.43). Ceres produced largest size (122.0 g) fruit while Winsari measured the tallest plant (120.5). Winsari produced highest marketable yield $\left(105.8 \mathrm{t} \mathrm{ha}^{-1}\right)$. Thus, it has been recommended for commercial production. Srijana, which has highest nutritional value needs to be promoted with increasing its productivity.
\end{abstract}

Key words: physicochemical, plastic house, rainy season, tomato

\section{Introduction}

Tomato (Solanum lycopersicum L.) is one of the major commercial vegetable crops and widely grown both in the Tarai and hills of Nepal. It is cultivated in 16,416 ha land in Nepal with a total production and productivity of 2, 82,481 and $17.71 \mathrm{tha}^{-1}$ respectively (VDD 2013). It cannot be grown in the plains during June-October owing to high temperature and stagnation of water in the field during rainy season. Plastic house technology and hybrid varieties have increased the possibility of tomato cultivation diurnal rainy season in high hills (Chapagain et al. 2011). Plastic house tomato cultivation technology is one of the successful technologies verified at Nepal Agricultural Research Council (NARC) and widely adopted by commercial farmers in western mid hills. However, continuous flow of new hybrid varieties and uncertainty of availability of desired varieties have created a dilemma among the farmers while selecting suitable tomato varieties. It emphasized the need for continuous varietal evaluation and provide sufficient varietal options for farmers. Moreover, varietal recommendation along with their physiochemical properties provides additional opportunity in varietal selection.

The growth environment of a tomato variety affects its composition (Caliman et al. 2010). The most important quality criteria for tomatoes in Nepal are red color, firm, juicy texture, and good flavor (Karki 2005). These characteristics are manifested in total soluble solids (TSS), juice content, acidity, vitamin C content, etc. Total solids content of cultivated tomato amount to 4.5 to $8.5 \%$ of its fresh weight (André et al. 2005), though this percentage can be much higher in some wild species (Bertin et al. 2000). Glucose and fructose are the major components of the soluble solids (Malundo et al. 1995).Total soluble solids contents (TSS) are important for the industrialization process as product yield is directly related to ${ }^{\circ} \mathrm{Brix}$, especially 
when the objective is dehydration, concentration of the pulp, or both (Stevens 1972). Lycopene, ascorbic $\operatorname{acid}($ vitamin $C$ ), and potassium contents are important for the nutritional value of tomato; they have beneficial effects on human health (Caliman et al. 2010). Tomatoes with high sugar and relatively high acid contents are the best flavored; low sugar and acid contents result in poor flavored tomatoes (Cantwell 1994). Vitamin C plays an important role in human health and it is found in fruits and vegetables in the form of ascorbic acid. Its main functions are in the prevention of scurvy and maintenance of skin and blood vessels (Lee \& Kader 2000).

\section{Methodology}

The experiment was conducted at the Regional Agricultural Research Station, Lumle (1640 m), Nepal. Six tomato hybrids namely; Makis, Ahmita, Dalila, Srijana, Ceres, Winsari and one open-pollinated variety (BL-410) were evaluated in randomized complete block design with four replications for two consecutive years, 2012 and 2013. Individual plot size was $7 \mathrm{~m}^{2}(2.8 \times 2.5$ m) with planting geometry of $70 \times 50 \mathrm{~cm}$. Twenty-five days old seedlings were transplanted during the second week of July, 2012 and 2013. The size of plastic house was $6 \mathrm{~m}$ wide and $20 \mathrm{~m}$ long with $2.80 \mathrm{~m}$ height at the center and $2 \mathrm{~m}$ at the side pole from soil surface. White coloured Silpaulin with the thickness of $120 \mathrm{~g}$ per square meter (GSM) was used as roofing material. Compost at the rate of $30 \mathrm{t}$ and NPK 75:100:100 kg $\mathrm{ha}^{-1}$ were applied as basal dose during field preparation and additional dose of nitrogen $75 \mathrm{~kg} \mathrm{ha}^{-1}$ was applied as top dressing at 30 days after transplanting. In addition, Miraculan was applied at the rate of $5 \mathrm{ml}$ per liter of water at monthly intervals after transplanting. Irrigation was done as and when necessary. Observations on days to flowering and harvest, number of clusters per plant, fruit diameter, average fruit weight, plant height and marketable fruit yield were recorded. Fruit samples were collected and analyzed at the Food Technology Division, NARC, Khumaltar for total soluble solids (TSS), total titratable acids (TTA), juice content and vitamin C.

\section{Determination of total soluble solids (TSS), vitamin- $C$ and acidity}

The TSS were measured by using Abbe refractometer and the values were corrected to $20^{\circ} \mathrm{C}$. The titrable acidity (as anhydrous citric acid) was determined by titrating the sample solution with $0.1 \mathrm{~N}$ of $\mathrm{NaOH}$ using
Phenolphthalein as an indicator. The vitamin-C content was determined by 2,6-dichlorophenol-indophenol visual titration method (Ranganna 1997).

Diseases and insects pests were observed regularly in tomatoes. Kryloxyl (Metalaxyl 8\% and Mancozeb 64\% a fungicides) was sprayed at the rate of $2 \mathrm{~g}$ / liters at 15 days interval after first observation of late blight disease. Imidacloprid was sprayed at the rate of $0.25 \mathrm{ml} /$ liter of water twice during the cropping season for controlling the white flies.

Analysis of variance (ANOVA) was computed for determining significance levels of variation among the treatments using Genstat Discovery Edition 3 (Genstat 2007) software. The significance of differences among treatment means were tested using Duncan's Multiple Range Test (DMRT) through MSTAT computer software (MSTAT 1990).

\section{Results and Discussion Chemical properties of tomato varieties}

Significant variation was recorded in total soluble solid (TSS), titrable acidity and vitamin C content among tomato varieties in pooled analysis of variance (Table 1). However, juice content did not vary. The highest juice content (69.00 $\%$ ) was recorded from Ceres and the lowest from Makish $(54.80 \%)$. The TSS ranged from 5.22 to $4.05{ }^{\circ} \mathrm{Bx}$. The highest TSS was obtained from open pollinated var. BL410 and the lowest from Winsari. BL-410 could be useful for processing industry. In the industry, this parameter dictates the factory yield in which the highest tomato total solids content amount to less tomato to be used to produce processed tomato product (Aoun, 2013).

Vitamin $\mathrm{C}$ content and the titrable acidity ranged from 32.32

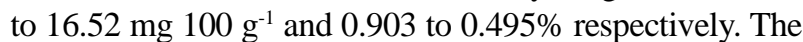
highest titrable acidity and vitamin $\mathrm{C}$ were obtained from Srijana. The result indicated that Srijana could be a useful variety from nutritional perspective. In addition, it has been known that higher fruit acidity is an advantage as it lowers the incidence for fungal infection in tomato (Mohammed et al. 1999).

The chemical composition obtained from the study was greater than those reported by Karki (2005) from open field condition in tomato var. Abinash-2. It could be due to the differences of tomato varieties and production condition. The growth environment of affects the compositions of tomato fruits (Caliman et al. 2010). 
Tika R. Chapagain et al/Physicochemical Properties.

Table 1. Mean values for chemical properties of tomato varieties under plastic house at Lumle during the years 2012 and 2013

\begin{tabular}{l|l|l|l|l}
\hline Varieties & Juice content $(\%)$ & Total soluble solid $\left({ }^{\circ} \mathrm{Bx}\right)$ & Vitamin C $\left({\left.\mathrm{mg} 100 \mathrm{~g}^{-1}\right)}^{\text {Titrable acidity }(\%)}\right.$ \\
\hline Ahmita & $58.10 \dagger$ & $5.15 \mathrm{a}$ & $17.68 \mathrm{bc}$ & $0.801 \mathrm{ab}$ \\
BL 410 & 68.30 & $5.22 \mathrm{a}$ & $16.52 \mathrm{c}$ & $0.857 \mathrm{a}$ \\
Ceres & 69.00 & $4.23 \mathrm{ab}$ & $17.10 \mathrm{c}$ & $0.552 \mathrm{bc}$ \\
Dalila & 59.80 & $4.95 \mathrm{ab}$ & $22.03 \mathrm{~b}$ & $0.739 \mathrm{abc}$ \\
Makis & 54.8 & $4.93 \mathrm{ab}$ & $20.65 \mathrm{bc}$ & $0.777 \mathrm{abc}$ \\
Srijana & 67.30 & $5.20 \mathrm{a}$ & $32.32 \mathrm{a}$ & $0.903 \mathrm{a}$ \\
Winsari & 60.60 & $4.05 \mathrm{~b}$ & $16.67 \mathrm{c}$ & $0.495 \mathrm{c}$ \\
Mean & 62.50 & 4.82 & 20.42 & 0.732 \\
P value & 0.309 & 0.05 & 4.001 & 0.025 \\
LSD $(0.05)$ & - & 0.888 & 17.4 & 0.2588 \\
CV(\%) & 19.5 & 15.5 & 29.8 \\
\hline
\end{tabular}

$\dagger$ Mean of 4 replications. In the columns means followed by the same letter are not significantly different $(p<0.05)$ by DMRT

Vegetative, flowering and fruit characteristics

Pooled analysis of variance carried out for all the characters differed significantly (Table 2). The tallest plant height $(120.50 \mathrm{~cm})$ was recorded in Winsari followed by Srijana $(118.40 \mathrm{~cm})$. The variety BL-410 took the least time to flowering (22.00 days), followed by Makis (26.00 days) and Winsari (26.00 days). Similarly, the cultivar BL-410 took 72.00 days to the first harvest and thus was the earliest one, while Dalila was the late variety taking 80.00 days for the first harvest after transplanting. The days to first harvest was envisaged as an index of earliness.

Table 2. Mean values for plant and yield contributing characteristics of tomato varieties under plastic house at Lumle during the years 2012 and 2013

\begin{tabular}{l|l|l|l|l|l|l|l}
\hline Varieties & $\begin{array}{l}\text { Plant } \\
\text { height }(\mathrm{cm})\end{array}$ & $\begin{array}{l}\text { Days to first } \\
\text { flowering }\end{array}$ & $\begin{array}{l}\text { Days to 50\% } \\
\text { flowering }\end{array}$ & $\begin{array}{l}\text { Days to first } \\
\text { fruiting }\end{array}$ & $\begin{array}{l}\text { Days to first } \\
\text { harvesting }\end{array}$ & Fruits/cluster & $\begin{array}{l}\text { Average fruit } \\
\text { weight }(\mathrm{g})\end{array}$ \\
\hline Ahmita & $108.6 \mathrm{ab}$ & $28.00 \mathrm{a} \dagger$ & $30.83 \mathrm{abc}$ & $33.67 \mathrm{a}$ & $78.00 \mathrm{abc}$ & $8.43 \mathrm{a}$ & $40.3 \mathrm{~d}$ \\
BL 410 & $105.0 \mathrm{bc}$ & $22.00 \mathrm{~b}$ & $27.83 \mathrm{~d}$ & $27.50 \mathrm{~b}$ & $71.50 \mathrm{~d}$ & $6.43 \mathrm{c}$ & $51.5 \mathrm{~cd}$ \\
Ceres & $114.9 \mathrm{ab}$ & $27.83 \mathrm{a}$ & $31.50 \mathrm{abc}$ & $32.50 \mathrm{a}$ & $79.00 \mathrm{ab}$ & $7.00 \mathrm{bc}$ & $122.0 \mathrm{a}$ \\
Dalila & $93.1 \mathrm{c}$ & $28.17 \mathrm{a}$ & $32.67 \mathrm{ab}$ & $33.17 \mathrm{a}$ & $80.00 \mathrm{a}$ & $7.37 \mathrm{bc}$ & $53.3 \mathrm{~cd}$ \\
Makis & $92.2 \mathrm{c}$ & $25.50 \mathrm{a}$ & $33.33 \mathrm{a}$ & $30.17 \mathrm{ab}$ & $75.33 \mathrm{bc}$ & $7.17 \mathrm{bc}$ & $63.3 \mathrm{c}$ \\
Srijana & $118.4 \mathrm{ab}$ & $26.50 \mathrm{a}$ & $30.33 \mathrm{bcd}$ & $30.50 \mathrm{ab}$ & $75.00 \mathrm{~cd}$ & $7.57 \mathrm{ab}$ & $53.3 \mathrm{~cd}$ \\
Winsari & $120.5 \mathrm{a}$ & $25.67 \mathrm{a}$ & $29.50 \mathrm{~cd}$ & $31.00 \mathrm{ab}$ & $78.50 \mathrm{abc}$ & $7.80 \mathrm{ab}$ & $80.7 \mathrm{~b}$ \\
Mean & 107.5 & 26.24 & 30.43 & 31.21 & 76.76 & 7.40 & 66.3 \\
P value & $<.001$ & $<.001$ & .012 & 0.004 & $<.001$ & $<.004$ & $<.001$ \\
LSD & 12.64 & 3.538 & 2.381 & 0.898 & 3.545 & 0.898 & 15.30 \\
(0.05) & & & & & & & \\
CV $(\%)$ & 9.9 & 8.0 & 6.6 & 10.2 & 3.9 & $10.2 \%$ & 19.4 \\
\hline
\end{tabular}

$\dagger$ Mean of 4 replications. In the columns means followed by the same letter are not significantly different $(p<0.05)$ by DMRT

Number of clusters per plant, number of flowers per cluster, and fruits per plant are the most important yield attributes in tomato (Pandey et al. 2006). Among the varieties tested, the maximum numbers of fruits per cluster (8.43) were observed in Ahmita while the largest average size of fruit (120.5 g) was recorded from Ceres. The trend observed in the results indicates that the higher yield depends on the number of fruits and weight of fruits per plant as well as earliness. It was apparent that fruit number and weight per plant showed a positive association with fruit yield of tomato.

\section{Marketable fruit yield (t ha-1)}

Pooled analysis of variance among the varieties on marketable fruit yield was highly significant (Fig.1). Winsari produced the highest marketable fruit yield (105.80 $\mathrm{t} \mathrm{ha}^{-1}$ ) followed by Ceres (99.9 $\left.\mathrm{t} \mathrm{ha}^{-1}\right)$. Marketable fruit yield is the major determinant character while selecting a particular variety for commercial cultivation (Chapagain et al. 2011). Winsari is very popular in the western hills of Nepal due to its productivity and medium sized fruits. 


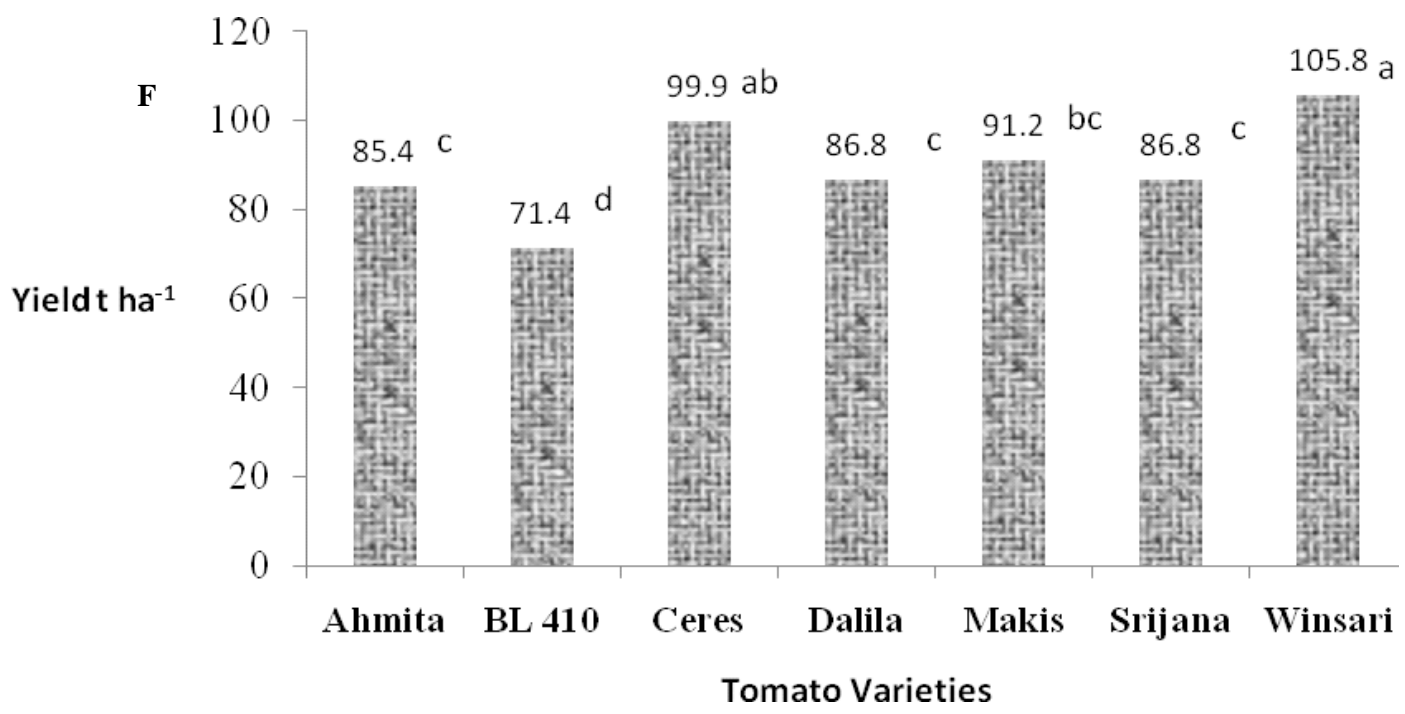

Fig. 1. Mean values for marketable fruit yield $\left(\mathrm{t} \mathrm{ha}^{-1}\right)$ of tomato varieties under plastic house at Lumle, during the years 2012 and 2013. In the figures same letters are not significantly different by DMRT at $P=0.05$

The greater TSS properties of BL-410 could be utilized in breeding program to increase the TSS of commercial varieties. Winsari, which produced the highest marketable fruit yield, is one of the popular varieties in Kaski district and should be up-scaled in similar agro-climatic zones of Nepal. Srijana having excellent nutritional value, needs further promotion with increasing its productivity. Further research on agronomical practices and varietal evaluation of tomatoes is needed to increase the productivity in plastic house production system.

\section{Acknowledgements}

We thank C. K. Timilsina, R. B. Basnet and P. B. Ghartimagar for their effort in trial implementation and data collection. Thanks are also offered to Mr. R. C. Adhikari for his constant support during the study. This research was conducted under the financial support of Nepal Agriculture Research Council (NARC), Nepal.

\section{References}

Aoun, A. B., B. Lechiheb, L. Benyahya and A. Frechichi. 2013. Evaluation of fruit quality traits of traditional varieties of tomato (Solanum lycopersicum) grown in Tunisia. African Journal of Food Science 7:350-354. http://www.academicjournal.org/AJFS.

Bertin, N., S. Guichard, C. Leonardi, J. J. Longenesse, D. Langlois and B. Navez. 2000. Seasonal evolution of the quality of fresh greenhouse tomatoes under Mediterranean conditions, affected by air vapour pressure deficit and plant fruit load. Ann. Bot. 85:741750.

Caliman, F. R. B., D. J. H da Silva, P. C. Sringheta, P. C. R. Fontesa, G. R. Moreira and E. C. Mantovani. 2010. Quality of tomatoes grown under a protected environment and field conditions. IDESIA 28:75-82.

Cantwell, M. 1994. Optimum procedures for ripening tomatoes. In: Management of Fruit Ripening, Post harvest Horticulture. Series No.9, Post harvest Outreach Program, Dept. of Pomology, University of California, Davis (UCDAVIS). pp. 22-28.

Chapagain, T. R., B. B. Khatri and J. L. Mandal. 2011. Performance of tomato varieties during rainy season under plastic house conditions. Nepal Journal of Science and Technology 12:17-22.

Genstat. 2007. Genstat for windows. Discovery edition 3. Lawes Agricultural Trust, Rothamsted Experimental Station, U.K.

Karki, D. B. 2014. Effect of harvesting stages on the quality of tomato (Lycopersicon esculentum Mill CV. Avinash-2, hybrid). Tribhuvan University Journal 1: 41-47.

Lee, S. K and A. A. Kader. 2000. Preharvest and postharvest factors influencing vitamin $\mathrm{C}$ content of horticultural crops. Postharvest Biology and Technology 20: 207 220.

Majid, R. F. 2007. Genome mapping and molecular breeding of tomato. International Journal of Plant Genomics p. 52.

Malundo, M. M., R. L. Shewfelt and J. W. Scott. 1995. Flavor quality of fresh tomato (Lycopersicon 
Tika R. Chapagain et al//Physicochemical Properties

esculentum Mill.) as affected by sugar and acid levels. Postharvest Biol. Technol. 6:103-110.

Mohammed, M., L. A. Wilson and P. L. Gomes.1999. Postharvest sensory and physiochemical attributes of processing and non-processing tomato cultivar. J. Food Qual. 22:167-182.

MSTATC. 1990. A Microcomputer program for the design, management, and analysis of agronomic research experiments. Michigan State Univ., East Lansing, USA.

Pandey, Y. R., A. B. Pun and K. P. Upadhyay. 2006. Participatory varietal evaluation of rainy season tomato under plastic house condition Nepal Agriculture Research Journal 7:11-15.
Ranganna, S. 1997. Handbook of analysis and quality control for fruits and vegetable products. 2 nd edn. New Delhi: Tata McGrawhill Publishing Company Ltd.

Stevens, M. A. 1972. Citrate and malate concentrations in tomato fruits: genetic control and maturational effects. Journal of the American Society for Horticultural Science 97:655-658.

VDD. 2013. Annual progress report (2068/2069). Vegetable Development Directorate, Agriculture Department, Ministry of Agriculture Development, Nepal. 89pp. 
Nepal Journal of Science and Technology Vol. 15, No.2 (2014) 17-22 